\title{
Oxidation treatment of diesel soot particulate on $\mathrm{Ce}_{x} \mathrm{Zr}_{1-x} \mathrm{O}_{2}$
}

\author{
Ling Zhu ${ }^{\mathrm{a}, *}$, Junjie Yu ${ }^{\mathrm{b}}$, Xuezhong Wang ${ }^{\mathrm{c}}$ \\ ${ }^{a}$ Department of Environmental Engineering, Beijing Institute of Petrochemical Technology, Qingyuan North Road 19, Beijing, 102617, PR China \\ ${ }^{\mathrm{b}}$ Research Center of Eco-Environmental Sciences, Chinese Academic Sciences, Shuangqing Road 18, Beijing 100085, PR China \\ ${ }^{\mathrm{c}}$ Chinese Research Academy of Environmental Sciences, Dayangfang Road 8, Beijing 100012, PR China
}

Received 9 December 2005; received in revised form 28 May 2006; accepted 19 June 2006

Available online 21 June 2006

\begin{abstract}
Catalytic oxidation of diesel soot particulate on $\mathrm{Ce}_{x} \mathrm{Zr}_{1-x} \mathrm{O}_{2}$ catalysts was investigated. Results indicated that Ce/Zr ratios had a significant influence on the catalytic activities. Compared with the ignition temperature $\left(T_{\mathrm{i}}\right)$ of uncatalyzed soot combustion, $T_{\mathrm{i}}$ of $\mathrm{Ce}_{0.5} \mathrm{Zr}_{0.5} \mathrm{O}_{2}$ with the best catalytic behavior decreased by $80^{\circ} \mathrm{C}$. The reactant gas compositions $\left(\mathrm{O}_{2}, \mathrm{H}_{2} \mathrm{O}\right.$ and NO) affected the catalytic activities too. $\mathrm{O}_{2}$-TPD, TG-DTA and XPS characterization results showed that $\mathrm{Ce}_{x} \mathrm{Zr}_{1-x} \mathrm{O}_{2}$ released lattice oxygen continuously to promote the soot combustion even no gas oxygen occurred in the reaction atmosphere. The mechanisms of spill-over and reduction/oxidation functioned synergistically for soot catalytic combustion. (C) 2006 Elsevier B.V. All rights reserved.
\end{abstract}

Keywords: $\mathrm{Ce}_{x} \mathrm{Zr}_{1-x} \mathrm{O}_{2}$ solid solution; Soot; Catalytic oxidation; Reaction mechanism

\section{Introduction}

The emissions of diesel engines are known to be hazardous pollutants for human health. One of the most dangerous components of diesel exhausts is particulate, which consists of agglomerates of small carbon particles with numbers of different hydrocarbons and sulphates adsorbed on their surfaces. A possible way to reduce particulate emission lies in filtering it with trap, and continuously burning out it on the presence of catalyst system which promotes particulate combustion at relatively low temperatures of the exhaust emission (below $400{ }^{\circ} \mathrm{C}$ ).

During the past decades, several catalysts were reported in references for soot oxidation, including perovskite-related oxides and spinel oxides [1,2], chloride-containing mixtures $[3,4]$, eutectic mixtures of oxides $[5,6]$, and noble metal catalysts $[7,8]$. However, only a few works involved soot combustion over rare earth oxide and its combined catalysts, relatively rare systemic research work reported soot combustion over Ce/Zr oxide catalysts.

Due to its oxygen storage capability (OSC) and redox properties $\left(\mathrm{Ce}^{4+} / \mathrm{Ce}^{3+}\right), \mathrm{CeO}_{2}$ had been widely used as oxygen storage material in three-way catalyst (TWC) [9]. Furthermore, as a main

\footnotetext{
* Corresponding author. Tel.: +86 10 81292291; fax: +86 1081292291.

E-mail addresses: zhuling75@bipt.edu.cn, zhuling7519@163.com (L. Zhu).
}

compound of the fuel additive, in this case cerium should be collected on the filter with the form of ceria, which promotes the combustion of soot trapped in the filter [10]. Relevant research shows that zirconium prevents the growth of $\mathrm{CeO}_{2}$ crystallites at high temperatures and improves the thermal stability of $\mathrm{CeO}_{2}$ [11].

This paper described the catalytic activities of $\mathrm{Ce} / \mathrm{Zr}$ series catalysts $\left(\mathrm{Ce}_{x} \mathrm{Zr}_{1-x} \mathrm{O}_{2}\right)$ for catalytic soot combustion in various feed gas compositions $\left(\mathrm{O}_{2}, \mathrm{NO}, \mathrm{H}_{2} \mathrm{O}\right)$. Catalyst structures were characterized by XRD and XPS techniques; the mechanism of soot combustion on $\mathrm{Ce}_{0.5} \mathrm{Zr}_{0.5} \mathrm{O}_{2}$ was explored by $\mathrm{O}_{2}$-TPD and TG-DTA.

\section{Experimental}

\subsection{Materials preparation}

$\mathrm{Ce}_{x} \mathrm{Zr}_{1-x} \mathrm{O}_{2}$ catalysts with different $\mathrm{Ce} / \mathrm{Zr}$ ratios $(x=0,0.3$, $0.5,0.7,1.0)$ were prepared by coprecipitation of aqueous $\mathrm{Ce}\left(\mathrm{NO}_{3}\right)_{3}$ and $\mathrm{ZrO}\left(\mathrm{NO}_{3}\right)_{2}$ solutions with $\mathrm{NH}_{3} \mathrm{H}_{2} \mathrm{O}$ as a coprecipitation agent. The precipitates were dried at $100{ }^{\circ} \mathrm{C}$ and calcined in the air at $700^{\circ} \mathrm{C}$ for $4 \mathrm{~h}$.

\subsection{Materials characterizations}

The oxygen storage capacity (OSC) was estimated by the thermo-gravimetric analysis (TAS-300, Rigaku Co., Ltd.) [12]. 
The textural properties of the samples were measured by nitrogen adsorption/desorption at liquid nitrogen temperature in a NOVA 1200 high-speed gas sorption analyzer.

XRD analysis was performed on a D/max 2400 diffractometer (Rigaku Co., Ltd.) with $\mathrm{Cu} \mathrm{K} \alpha$ radiation. Diffraction peaks of crystalline phases were compared with those of standard compounds reported in the JCPDS Data File.

$\mathrm{O}_{2}$ temperature programmed desorption $\left(\mathrm{O}_{2}-\mathrm{TPD}\right)$ was carried out by a conventional TPO apparatus connected to a chromatography according to the following procedure: catalyst sample was heated to $500^{\circ} \mathrm{C}$ in the helium atmosphere and held for $1 \mathrm{~h}$, then cooled down to room temperature and started the TPD test for two circles. The temperature of reactor bed was raised with a heating rate of $10^{\circ} \mathrm{C} / \mathrm{min}$ and all the TPO experiments were conducted in the helium atmosphere.

$\mathrm{X}$-ray photoelectron spectra (XPS) were acquired with a VGESCALAB MKII spectrometer equipped with a hemispherical electron analyzer and $\mathrm{Mg} \mathrm{K} \alpha \mathrm{X}$-ray source. All binding energies (B.E.) were referenced to the $\mathrm{C} 1 \mathrm{~s}$ line at $284.6 \mathrm{eV}$, which provided binding energy values with an accuracy of $\pm 0.2 \mathrm{eV}$.

\subsection{Activity evaluation}

Model soot was the Printex-U supplied by Degussa. Before reaction, soot was carefully mixed with the catalyst, in the ratio of 1/10. Mixing in this way resulted in a "loose" contact between the catalyst and soot, which was assumed to be close to that found in practical cases.

The activities were evaluated in temperature programmed oxidation (TPO) reactor. Soot-catalyst mixture $(110 \mathrm{mg})$ was placed into the quartz reactor $(\varphi=10 \mathrm{~mm})$ and performed in the range $30-700^{\circ} \mathrm{C}$ (at a heating rate of $10^{\circ} \mathrm{C} / \mathrm{min}$ ) in the flowing gas $\left(10 \% \mathrm{O}_{2} / \mathrm{N}_{2}\right.$, with a flow rate of $\left.500 \mathrm{ml} / \mathrm{min}\right)$. A nondispersive IR gas analyzer (TY-9800A) was used to monitor the concentration of $\mathrm{CO}_{2}$ continuously.

About $1000 \mathrm{ppm} \mathrm{NO}$ and $7 \% \mathrm{H}_{2} \mathrm{O}$ were added into $10 \% \mathrm{O}_{2} / \mathrm{N}_{2}$ to explore the effect of the reactant gas composition on the catalytic activity of $\mathrm{Ce}_{0.5} \mathrm{Zr}_{0.5} \mathrm{O}_{2}$.

\section{Results and discussion}

\subsection{OSC and BET surface area}

Table 1 shows the OSC properties and BET surface area of the $\mathrm{Ce}_{x} \mathrm{Zr}_{1-x} \mathrm{O}_{2}$ samples. When $\mathrm{ZrO}_{2}$ added into $\mathrm{CeO}_{2}$, its OSC is obviously increased and the $\mathrm{OSC}$ of $\mathrm{Ce}_{0.5} \mathrm{Zr}_{0.5} \mathrm{O}_{2}$ reaches the maximum. OSC is irrelevant to the surface area.

Table 1

Characteristic parameters of $\mathrm{Ce}_{x} \mathrm{Zr}_{1-x} \mathrm{O}_{2}$ catalysts

\begin{tabular}{lcl}
\hline Catalyst sample & BET surface area $\left(\mathrm{m}^{2} / \mathrm{g}\right)$ & OSC $(\mu \mathrm{mol} \mathrm{O} / \mathrm{g})$ \\
\hline $\mathrm{CeO}_{2}$ & 58.22 & 137.09 \\
$\mathrm{Ce}_{0.7} \mathrm{Zr}_{0.3} \mathrm{O}_{2}$ & 130.82 & 396.05 \\
$\mathrm{Ce}_{0.5} \mathrm{Zr}_{0.5} \mathrm{O}_{2}$ & 132.61 & 439.85 \\
$\mathrm{Ce}_{0.3} \mathrm{Zr}_{0.7} \mathrm{O}_{2}$ & 121.8 & 277 \\
$\mathrm{ZrO}_{2}$ & 30.9 & 0 \\
\hline
\end{tabular}

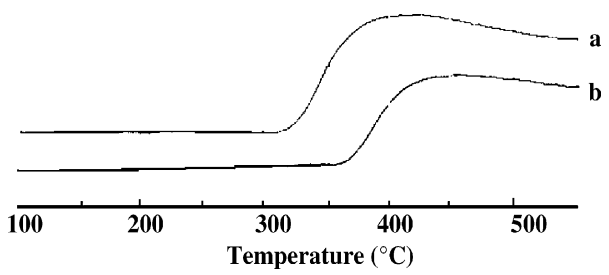

Fig. 1. $\mathrm{O}_{2}$-TPD curves of $\mathrm{Ce}_{0.5} \mathrm{Zr}_{0.5} \mathrm{O}_{2}$ : (a) the first test; (b) the second test.

\subsection{XRD analysis}

XRD results (XRD patterns were not given in this paper) indicate that the structure of $\mathrm{CeO}_{2}$ corresponded to a single phase of fluorite-type structure. When $\mathrm{ZrO}_{2}$ added into $\mathrm{CeO}_{2}$, the related peaks move to higher angle value and the peak become broader; the crystal phase of $\mathrm{Ce}_{0.3} \mathrm{Zr}_{0.7} \mathrm{O}_{2}$ shift from cubic to tetragonal construction [13]. Whatever the percentage of $\mathrm{ZrO}_{2}$ added, no $\mathrm{ZrO}_{2}$ phases are detected, therefore, $\mathrm{Ce}_{x} \mathrm{Zr}_{1-x} \mathrm{O}_{2}$ samples are in a homogeneous phase.

\section{3. $\mathrm{O}_{2}-\mathrm{TPD}$ analysis}

Generally, there are three kinds of active oxygen species: $\alpha$, $\beta$, and $\gamma$ on surface of $\mathrm{Ce}-\mathrm{Zr}$ solid solution. $\alpha \mathrm{O}$ species has a lower desorption temperature $\left(<350^{\circ} \mathrm{C}\right)$, which is assigned to the chemical adsorption oxygen; $\gamma \mathrm{O}$ species has a higher desorption temperature $\left(>750^{\circ} \mathrm{C}\right)$, being assigned to the oxygen in crystal lattice. However, desorption temperature of $\beta \mathrm{O}$ species is between these two desorption temperatures, which is related with oxygen defect and is considered as partial crystal oxygen [14].

The $\mathrm{O}_{2}$-TPD curves of $\mathrm{Ce}_{0.5} \mathrm{Zr}_{0.5} \mathrm{O}_{2}$ were shown in Fig. 1 . The peak temperature matches up to the desorption temperature of $\beta \mathrm{O}$ species, so these peaks represented some kind of $\beta O$ species. It could be seen from these curves that the catalyst released oxygen continuously when its temperature raised. This is an important character when the catalyst was used for soot combustion in the condition of lacking of oxygen as oxidant.

\subsection{TPO experiment}

The activity of catalyst in TPO evaluation was represented by the ignition temperature $\left(T_{\mathrm{i}}\right)$ and the peak temperature $\left(T_{\mathrm{p}}\right)$. $T_{\mathrm{i}}$ and $T_{\mathrm{p}}$ were defined as the temperatures where the concentration of $\mathrm{CO}_{2}$ exceeds $20 \mathrm{ppm}$ at $5^{\circ} \mathrm{C}$ interval and where the maximum $\mathrm{CO}_{2}$ emitted. According to the Redhead method, we estimated the activation energy of soot combustion by the following equations [15]:

$A \frac{E_{\mathrm{a}}}{R T_{\mathrm{p}}} \mathrm{e}^{-E a / R T}=\frac{\alpha E_{\mathrm{a}}}{R T_{\mathrm{p}}^{2}}$

where $A$ is the Arrhenius pre-exponential, $E_{\mathrm{a}}$ the activation energy terms and $\alpha$ is the heating rate.

The TPO results were shown in Table 2 and Fig. 2. Without catalyst, the soot oxidation begins at $490^{\circ} \mathrm{C}$ and the $T_{\mathrm{p}}$ 
Table 2

Soot oxidation activities on various catalysts in TPO evaluation

\begin{tabular}{lllll}
\hline Catalyst & $T_{\mathrm{i}}\left({ }^{\circ} \mathrm{C}\right)$ & $T_{\mathrm{p}}\left({ }^{\circ} \mathrm{C}\right)$ & $\Delta T\left({ }^{\circ} \mathrm{C}\right)$ & $E_{\mathrm{a}}(\mathrm{kJ} / \mathrm{mol})$ \\
\hline Without catalyst & 490 & 595 & 105 & 159.43 \\
$\mathrm{CeO}_{2}$ & 445 & 573 & 128 & 155.20 \\
$\mathrm{Ce}_{0.7} \mathrm{Zr}_{0.3} \mathrm{O}_{2}$ & 425 & 543 & 118 & 149.47 \\
$\mathrm{Ce}_{0.5} \mathrm{Zr}_{0.5} \mathrm{O}_{2}$ & 410 & 525 & 110 & 146.04 \\
$\mathrm{Ce}_{0.3} \mathrm{Zr}_{0.7} \mathrm{O}_{2}$ & 460 & 559 & 119 & 152.53 \\
$\mathrm{ZrO}_{2}$ & 490 & 595 & 105 & 159.43 \\
\hline
\end{tabular}

is around $595^{\circ} \mathrm{C} ; \mathrm{ZrO}_{2}$ shows no catalytic activity for soot combustion. The performances of Ce-based catalysts are obviously enhanced. Compared with the result of uncatalyzed soot combustion, $T_{\mathrm{i}}$ and $T_{\mathrm{p}}$ on Ce-based catalysts shift to lower temperature by $30-80^{\circ} \mathrm{C}$ at the different $\mathrm{Ce} / \mathrm{Zr}$ ratios. $\mathrm{Ce}_{0.5} \mathrm{Zr}_{0.5} \mathrm{O}_{2}$ has the best catalytic performance, its $T_{\mathrm{i}}$ and $T_{\mathrm{p}}$ decrease by 80 and $70^{\circ} \mathrm{C}$, respectively. The calculated results of reaction energies are accordant with the catalytic activities.

The introduction of $\mathrm{ZrO}_{2}$ (seven-fold coordination) into $\mathrm{CeO}_{2}$ (eight-fold coordination) may lead to the reduction of element numbers in crystal grain and the aberrance of adjacent oxygen atom, which makes it easier to deviate from the crystal lattice to become the interstice atom [16]. At the same time, the effective ionic radii of $\mathrm{Ce}^{4+}, \mathrm{Ce}^{3+}$ and $\mathrm{Zr}^{4+}$ are $0.097,0.114$ and $0.084 \mathrm{~nm}$, respectively [16]. The introduction of the small size zirconium ions into the cerium framework may compensate for the volume expansion, hence facilitate the process of valence change. As a result, $T_{\mathrm{i}}$ of soot combustion decreases gradually. $T_{\mathrm{i}}$ of soot on $\mathrm{Ce}_{0.5} \mathrm{Zr}_{0.5} \mathrm{O}_{2}$ is lowered by $80^{\circ} \mathrm{C}$. This may contribute to the number of adjacent oxygen coordination around $\mathrm{Zr}^{4+}$ decreasing from 7 to 6 . On the contrary, introducing more $\mathrm{ZrO}_{2}$ to $\mathrm{CeO}_{2}, \mathrm{Ce}_{0.3} \mathrm{Zr}_{0.7} \mathrm{O}_{2}$ becomes a new tetragonal structure: the increase of the lattice parameters $c / a$ and the augment of crystal anisotropy [17], which blocks the oxygen release and move. Therefore, $T_{\mathrm{i}}$ and $T_{\mathrm{p}}$ of $\mathrm{Ce}_{0.3} \mathrm{Zr}_{0.7} \mathrm{O}_{2}$ catalyst are increased.

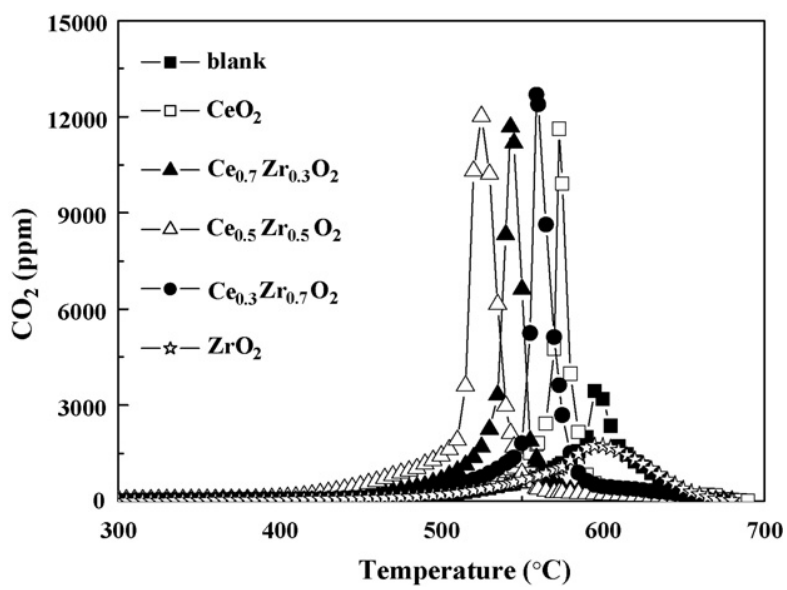

Fig. 2. Catalytic performance of $\mathrm{Ce}_{x} \mathrm{Zr}_{1-x} \mathrm{O}_{2}$ for soot oxidation in TPO.
Table 3

Effect of feed gas composition on the catalytic performance of $\mathrm{Ce}_{0.5} \mathrm{Zr}_{0.5} \mathrm{O}_{2}$ for soot combustion

\begin{tabular}{llll}
\hline Feed gas composition & $T_{\mathrm{i}}\left({ }^{\circ} \mathrm{C}\right)$ & $T_{\mathrm{p}}\left({ }^{\circ} \mathrm{C}\right)$ & $\Delta T\left({ }^{\circ} \mathrm{C}\right)$ \\
\hline $10 \% \mathrm{O}_{2}-\mathrm{N}_{2}$ & 410 & 525 & 115 \\
$10 \% \mathrm{O}_{2}-7 \% \mathrm{H}_{2} \mathrm{O}-\mathrm{N}_{2}$ & 410 & 525 & 115 \\
$10 \% \mathrm{O}_{2}-1000$ ppm NO- $\mathrm{N}_{2}$ & 380 & 500 & 120 \\
$10 \% \mathrm{O}_{2}-1000$ ppm NO-7\% $\mathrm{H}_{2} \mathrm{O}-\mathrm{N}_{2}$ & 385 & 500 & 115
\end{tabular}

\subsection{Effect of feed gas compositions on the catalytic performance of $\mathrm{Ce}_{0.5} \mathrm{Zr}_{0.5} \mathrm{O}_{2}$ for soot oxidation}

\subsubsection{Effect of feed gas compositions on the soot combustion without catalyst}

As shown in Table 3 and Fig. 3, in the absence of NO, the addition of $\mathrm{H}_{2} \mathrm{O}$ has little effect on the $T_{\mathrm{i}}$ and the reaction rate. This phenomenon is consistent with the reported results that the experimental activation energies of soot combustion without catalysts in $10 \% \mathrm{O}_{2}-\mathrm{N}_{2}$ and $10 \% \mathrm{O}_{2}-10 \% \mathrm{H}_{2} \mathrm{O}-\mathrm{N}_{2}$ are 168 and $169 \mathrm{~kJ} / \mathrm{mol}$, respectively [18]. The reaction of NO oxidation is an exothermic process, and $\mathrm{NO}_{2}$ concentration and rate of soot oxidation with $\mathrm{NO}_{2}$ do not increase with the raising of temperature. So, the addition of NO does not affect the $T_{\mathrm{i}}$ of soot combustion. On the contrary, the competitive reaction with active oxygen between soot and NO results in the increase of $T_{\mathrm{p}}$ by $5-25^{\circ} \mathrm{C}$.

\subsubsection{Effect of $\mathrm{O}_{2}$ concentration on the catalytic performance of $\mathrm{Ce}_{0.5} \mathrm{Zr}_{0.5} \mathrm{O}_{2}$ for soot oxidation}

When the concentration of $\mathrm{O}_{2}$ exceeds $8.5 \%$, there was no influence on soot combustion and $T_{\mathrm{i}}$ and $T_{\mathrm{p}}$ remain at 410 and $525^{\circ} \mathrm{C}$ (seen from Fig. 4). When the concentration of $\mathrm{O}_{2}$ is $1-8.5 \%$, with the decrease of $\mathrm{O}_{2}$ concentration, $T_{\mathrm{i}}$ has not been changed; however, $T_{\mathrm{p}}$ increases from 525 to $580^{\circ} \mathrm{C}$ and the reaction rate slows down. Inui et al. [19] reported that the concentration of $\mathrm{O}_{2}$ greatly affected on the rate-determined step during the course of soot combustion. The absorption of oxygen on the catalysts surface has a very quick velocity and a

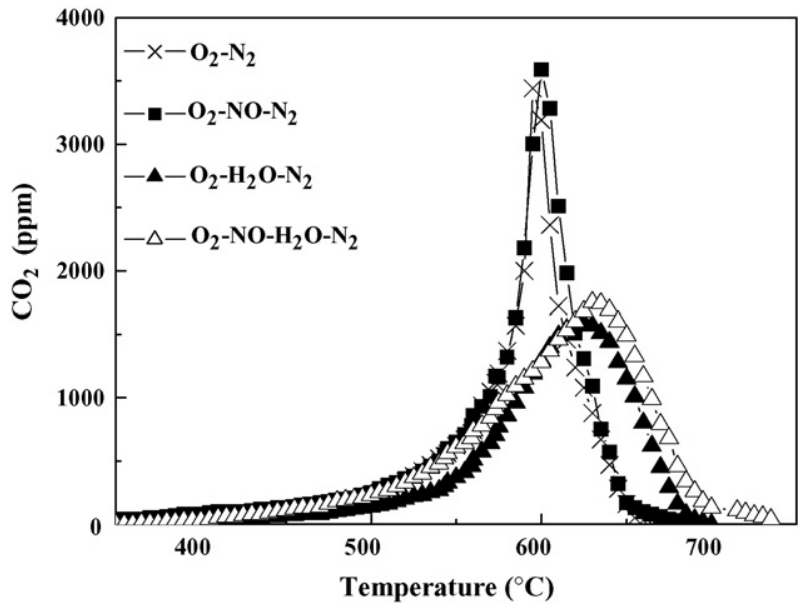

Fig. 3. Effect of the composition of reaction gas on the soot oxidation without catalysts. 


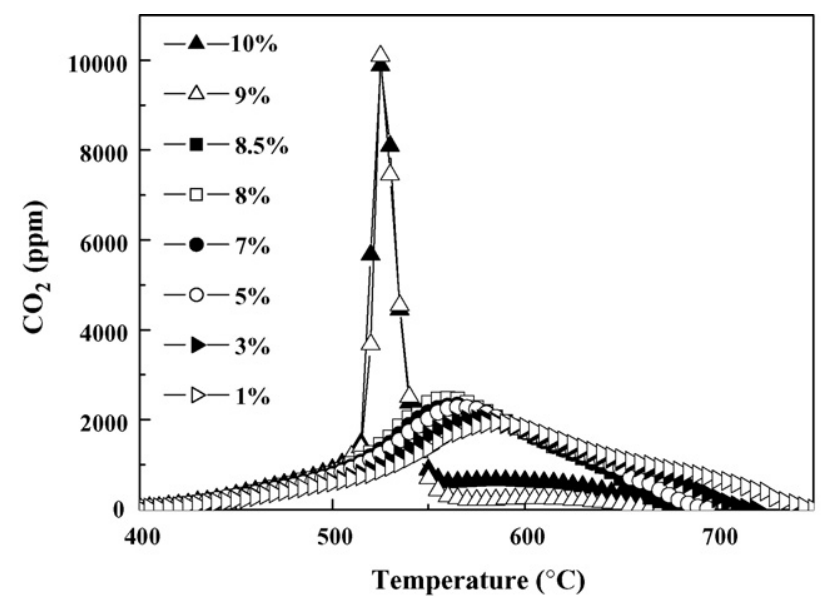

Fig. 4. Effect of $\mathrm{O}_{2}$ concentration on catalytic soot oxidation on $\mathrm{Ce}_{0.5} \mathrm{Zr}_{0.5} \mathrm{O}_{2}$.

very high intensity. When the reaction atmosphere has a high $\mathrm{O}_{2}$ concentration ( $>8.5 \%$ ), the rate-determined step is the oxygen transference on the catalyst surface, and compared with the active oxygen species released from catalysts, desorption gaseous oxygen is the main surface active oxygen species. When the reaction atmosphere contains the low concentration of $\mathrm{O}_{2}$ $(<8.5 \%)$, the rate-determined step is the absorption of $\mathrm{O}_{2}$ on the catalysts surface and the transference velocity of $\mathrm{O}_{2}$ inside the catalysts is very quick. With the decrease of $\mathrm{O}_{2}$ concentration, the quantity of absorption oxygen reduces and the active oxygen species reduces accordingly. Therefore the oxidation velocity of $\mathrm{CeO}_{2-Y}$ becomes slow, which influences the rate of releasing oxygen. As shown in Fig. 5, with the fall of $\mathrm{O}_{2}$ concentration, the rate of soot combustion gradually lowers and the $T_{\mathrm{p}}$ increases.

\subsubsection{Effect of $\mathrm{H}_{2} \mathrm{O}$ and $\mathrm{NO}$}

From Fig. 5 we found that the addition of $7 \% \mathrm{H}_{2} \mathrm{O}$ has no effect on soot combustion over $\mathrm{Ce}_{0.5} \mathrm{Zr}_{0.5} \mathrm{O}_{2}$. It means that the $\mathrm{Ce}-\mathrm{Zr}$ solid solution has an excellent water tolerance and thermal stability. When NO is added to the reactant gas, $T_{\mathrm{i}}$ decreases by $30^{\circ} \mathrm{C}$ and the TPO curves becomes relatively flat. It indicates that $\mathrm{NO}$ plays an important role in soot combustion on $\mathrm{Ce}_{0.5} \mathrm{Zr}_{0.5} \mathrm{O}_{2}$. The active oxygen $\left(\mathrm{O}^{*}\right)$ formed on the

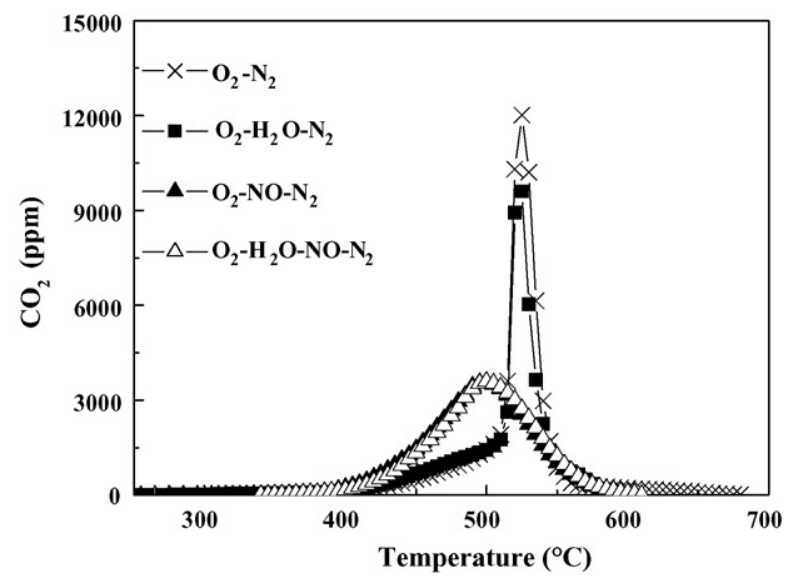

Fig. 5. Effect of the composition of reaction gas on the soot oxidation on $\mathrm{Ce}_{0.5} \mathrm{Zr}_{0.5} \mathrm{O}_{2}$.
$\mathrm{Ce}_{0.5} \mathrm{Zr}_{0.5} \mathrm{O}_{2}$ surface reacts with $\mathrm{NO}$ and converts into $\mathrm{NO}_{2}$. $\mathrm{NO}_{2}$ has spatial configuration and the $\mathrm{N}-\mathrm{O}$ band in the $\mathrm{NO}_{2}$ molecule is easy to be broken, therefore the oxidation activity of soot with $\mathrm{NO}_{2}$ is higher than $\mathrm{O}_{2} . T_{\mathrm{i}}$ decreases by $30^{\circ} \mathrm{C}$, which may be due to lower reaction temperature of soot and $\mathrm{NO}_{2}$ (about at $275^{\circ} \mathrm{C}$ in term of thermodynamics calculation). Along with soot combustion, both $\mathrm{NO}$ and $\mathrm{CO}_{2}$ are absorbed in the alkaline sites and the absorption-desorption rate of intermediate compound decreases. Due to $\mathrm{O}^{*}$ competition between $\mathrm{NO}$ and soot, the combustion course becomes slower. Baker and Chludzinski [20] reported that the process of $\mathrm{CO}_{2}$ formation from the interaction between $\mathrm{NO}_{2}$ and proceeds through the oxidation of active sites on the soot surface, via abstraction of oxygen atoms from $\mathrm{NO}_{2}$ to produce partially oxidized surface species $(>\mathrm{C}=\mathrm{O})$ and NO. Oi-Uchisawa et al. [8] also found the same phenomenon for soot combustion over $\mathrm{Pt} / \mathrm{SiO}_{2}$ in the present of NO.

\subsection{Mechanistic aspect}

The oxygen involved for soot combustion comes from two aspects as follow: the gaseous oxygen and the oxygen released from catalysts; thus the soot oxidation on $\mathrm{Ce}_{x} \mathrm{Zr}_{1-x} \mathrm{O}_{2}$ catalyst should be occurred the following two reaction process:

$\mathrm{C}+\mathrm{O}_{2} \rightarrow \mathrm{CO}_{2}$

$\mathrm{CeO}_{2}+\mathrm{C} \rightarrow \mathrm{CO}+\mathrm{CO}_{2}+\mathrm{CeO}_{2-Y}$

The better catalytic activity may contribute from the dissociation centres for the adsorption oxygen $\left(\mathrm{O}_{2}\right.$ ads $)$ provided by the metal oxides [21]. On the surface of $\mathrm{CeO}_{2}, \mathrm{O}_{2}$ ads (with surplus odd $2 \mathrm{~d}$ electrons) bond with $\mathrm{Ce}$ (with empty orbits) and give bonded oxygen in the form of $\pi$ bond, the outer electron cloud of oxygen atom become unsymmetrical. Accepted external energies, $\pi$ bond would be broken and dissociated into various surface $\mathrm{O}$ species $\left(\mathrm{O}^{*}\right)$, especially bonded with the $\mathrm{Ce}$ atom near the $\mathrm{Ce}_{x} \mathrm{Zr}_{1-x} \mathrm{O}_{2}$ surface defect. To Eq. (1), gaseous oxygen is absorbed on the catalyst surface (Eq. (3)) and the absorption oxygen is dissociated to a series of surface oxygen species $\left(\mathrm{O}^{*}\right)$, such as $\mathrm{O}$ radicals $\left(\mathrm{O}^{\bullet}\right)$, superoxide radicals $\left(\mathrm{O}^{-}\right.$, $\mathrm{O}_{2}{ }^{-}, \mathrm{O}_{2}{ }^{2-}$, etc.) (Eq. (4)). These $\mathrm{O}^{*}$ are transferred to the soot surface through the spill-over effect, then attack the soot to give an oxygen-containing active intermediate $\left(\mathrm{C}-\mathrm{O}^{*} \mathrm{~s}\right), \mathrm{CO}_{(\mathrm{ads})}$ and $\mathrm{CO}_{2 \text { (ads) }}$ (Eq. (5)). The detail of $\mathrm{C}-\mathrm{O}^{*} \mathrm{~s}$ is still not clear at present, but the presence of such an oxygen-containing reactive surface complex is confirmed on the char surface after reaction with gaseous oxygen. Decomposition of the $\mathrm{C}-\mathrm{O}$ *s results in the formation of $\mathrm{CO}_{(\mathrm{ads})}$ and $\mathrm{CO}_{2(\mathrm{ads})}$ (Eq. (6)), the $\mathrm{CO}_{(\text {ads })}$ and $\mathrm{CO}_{2(\mathrm{ads})}$ are desorbed from the soot surface into the air at last

$\mathrm{O}_{2} \rightarrow \mathrm{O}_{2 \text { (ads) }}$

$\mathrm{O}_{2(\mathrm{ads})} \rightarrow 2 \mathrm{O} \rightarrow 2 \mathrm{O}^{*}\left[\mathrm{O}^{*}, \mathrm{O}^{-}, \mathrm{O}_{2}{ }^{-}, \mathrm{O}_{2}{ }^{2-}\right]$

$\mathrm{O}^{*}+\mathrm{C} \rightarrow \mathrm{C}-\mathrm{O}^{*} \mathrm{~s}+\mathrm{CO}_{(\mathrm{ads})}+\mathrm{CO}_{2(\mathrm{ads})}$

$\mathrm{C}-\mathrm{O}^{*} \mathrm{~s}+\mathrm{CO}_{(\mathrm{ads})}+\mathrm{O}^{*} \rightarrow \mathrm{CO}_{2(\mathrm{ads})}$

Meanwhile, $\mathrm{Ce}_{x} \mathrm{Zr}_{1-x} \mathrm{O}_{2}$ catalysts have a high oxygen storage capacity. Through spill-over effect, oxygen released from 


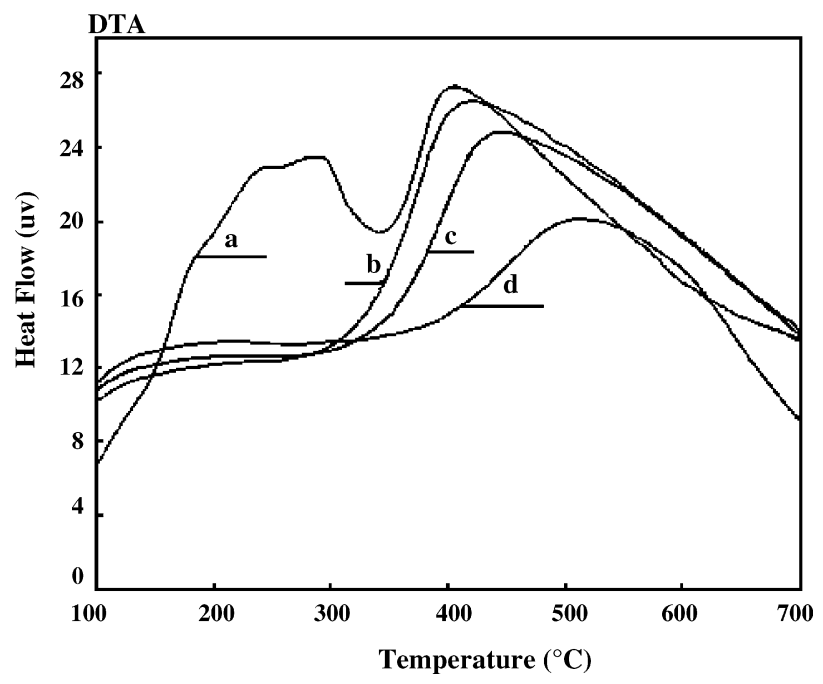

Fig. 6. TG-DTA result of soot combustion on $\mathrm{Ce}_{0.5} \mathrm{Zr}_{0.5} \mathrm{O}_{2}$ in $\mathrm{N}_{2}$ atmosphere: (a) the first test; (b) the second test; (c) the third test; (d) the fourth test.

$\mathrm{Ce}_{x} \mathrm{Zr}_{1-x} \mathrm{O}_{2}$ (Eq. (7)) react with soot and form $\mathrm{CO}$ and $\mathrm{CO}_{2}$ (Eqs. (5) and (6)); at the same time, $\mathrm{CeO}_{2-Y}$ in reductive state are oxidized to $\mathrm{CeO}_{2}$ (Eq. (8)). This process is preceded through reduction/oxidation mechanism:

$$
\begin{aligned}
& \mathrm{CeO}_{2} \rightarrow \mathrm{CeO}_{2-Y}+x \mathrm{O}^{*} \\
& \mathrm{O}^{*}+\mathrm{C} \rightarrow \mathrm{C}-\mathrm{O}^{*} \mathrm{~s}+\mathrm{CO}_{(\text {ads })}+\mathrm{CO}_{2(\text { ads })} \\
& \mathrm{C}-\mathrm{O}^{*} \mathrm{~s}+\mathrm{CO}_{(\text {ads })}+\mathrm{O}^{*} \rightarrow \mathrm{CO}_{2 \text { (ads) }} \\
& \mathrm{CeO}_{2-Y}+\mathrm{YO}^{*} \rightarrow \mathrm{CeO}_{2}
\end{aligned}
$$

The two mechanisms of spill-over and reduction/oxidation function synergistically for soot combustion [21].

To prove the existence of reduction/oxidation function, TG-DTA curves of $\mathrm{Ce}_{0.5} \mathrm{Zr}_{0.5} \mathrm{O}_{2}$ of four test circles in high purity nitrogen atmosphere were conducted and the results were shown in Fig. 6.

There are two exothermic peaks on DTA curve in the first test cycle, however only one peak in the other cycles. The first peak $\left(200-300^{\circ} \mathrm{C}\right)$ in the first circle can be ascribed to the reaction of soot with absorbed oxygen. The second peak (above $300{ }^{\circ} \mathrm{C}$ ) is consistent to the peak in the $\mathrm{O}_{2}$-TPD experiment under the He atmosphere (Fig. 1). At the same time, the peak temperature moves to higher value as the test cycle increases. The second peak is due to the reaction between the soot and desorbed lattice oxygen (so-called "stored" oxygen). Along with the consumption of oxygen, the energy needed to release residual oxygen in lattice becomes higher, which is accordant with the increase of peak temperature and the decrease of peak area in the following reactions cycles.

$\mathrm{Ce}_{0.5} \mathrm{Zr}_{0.5} \mathrm{O}_{2}$ and $\mathrm{Ce}_{0.5} \mathrm{Zr}_{0.5} \mathrm{O}_{2}$ after the above TG experiments are also analyzed by XPS. The $\mathrm{O} 1 \mathrm{~s}$ spectra are fitted with two peak contributions, referred to as $\mathrm{O}_{\mathrm{I}}$ and $\mathrm{O}_{\mathrm{II}}$ components, as showed in Table 4 and Fig. 7. The major peak component $\mathrm{O}_{\mathrm{I}}$ with B.E. at $528.9-529.7 \mathrm{eV}$ is characteristic of lattice oxygen. Component $\mathrm{O}_{\text {II }}$ with B.E. at $531.0-532.0 \mathrm{eV}$ belongs most likely to the adsorbed oxygen or the surface hydroxyl species
Table 4

Quantitative aspects of analyses of sample by XPS

\begin{tabular}{llll}
\hline Catalyst & $\mathrm{O}_{\mathrm{I}}^{\mathrm{a}}(\%)$ & $\mathrm{O}_{\mathrm{II}}^{\mathrm{b}}(\%)$ & $\mathrm{Ce}^{4+} / \mathrm{Ce}^{3+}(\%)$ \\
\hline $\mathrm{Ce}_{0.5} \mathrm{Zr}_{0.5} \mathrm{O}_{2}$ & 71.15 & 28.85 & 62 \\
$\mathrm{Ce}_{0.5} \mathrm{Zr}_{0.5} \mathrm{O}_{2}$ (after TG experiment) & 81.97 & 18.03 & 51 \\
\hline
\end{tabular}

a The lattice oxygen.

b The adsorbed oxygen or the surface hydroxyl species.
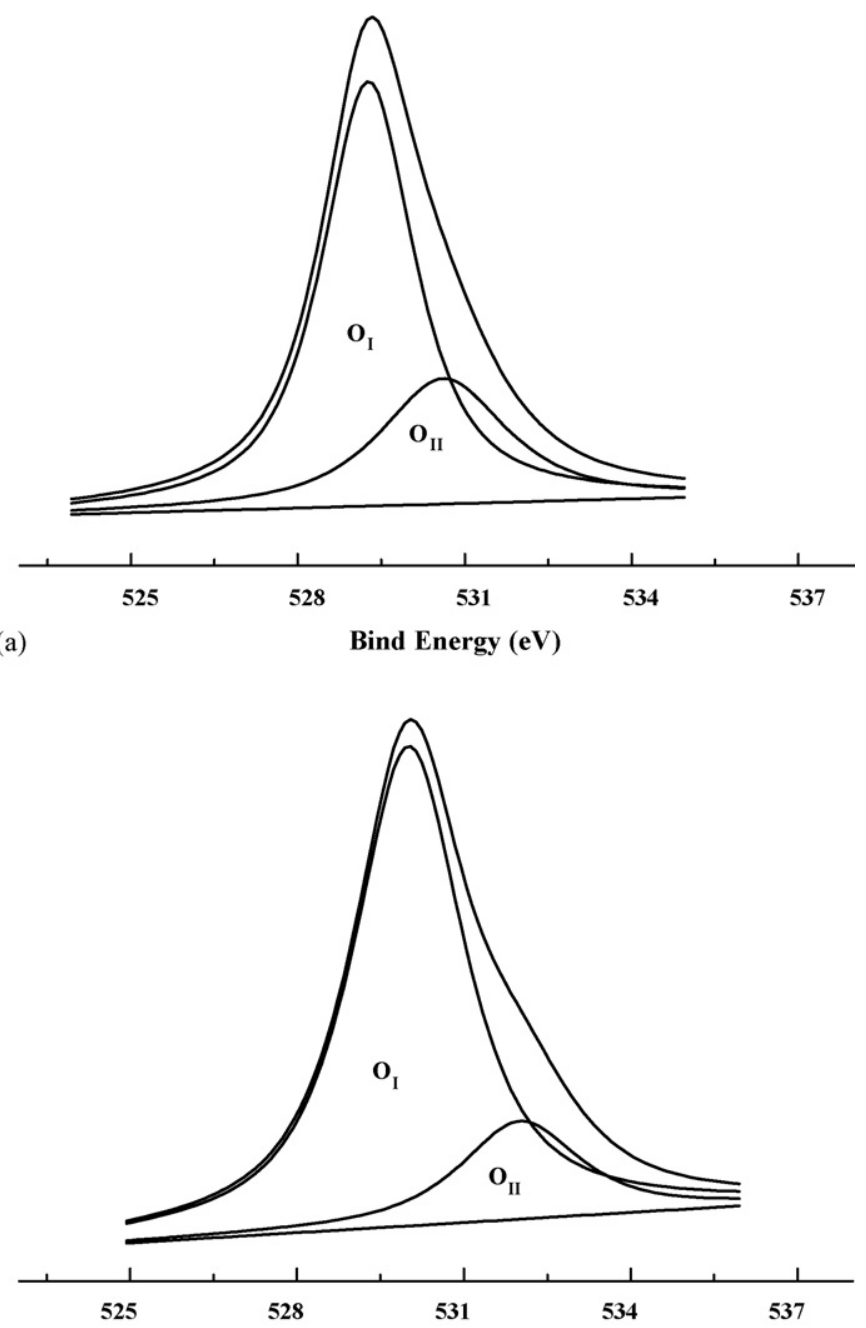

(b)

Bind Energy (eV)

Fig. 7. XPS O 1s spectra of the samples: (a) fresh $\mathrm{Ce}_{0.5} \mathrm{Zr}_{0.5} \mathrm{O}_{2}$; (b) $\mathrm{Ce}_{0.5} \mathrm{Zr}_{0.5} \mathrm{O}_{2}$ after the above TG reaction.

[22]. Compared with the fresh sample, the $\mathrm{O}_{\mathrm{II}} \%$ in the sample after TG experiment is decreased from 28.85 to $18.03 \%$ and the $\mathrm{Ce}^{4+} \%$ is changed from 62 to $51 \%$ accordingly. These results indicates that the $\mathrm{O}_{\mathrm{I}}$ takes part in the reaction of soot combustion and part of $\mathrm{O}^{*}$ are offered by the deoxidizing $\mathrm{CeO}_{2}$ to $\mathrm{Ce}_{2} \mathrm{O}_{3}$, which is consistent with the above TG experiment.

\section{Conclusions}

$\mathrm{Ce}_{x} \mathrm{Zr}_{1-x} \mathrm{O}_{2}$ catalysts promote the soot combustion and have good water tolerance and thermal stability. $\mathrm{Ce} / \mathrm{Zr}$ ratios affect 
the catalytic activities greatly and the $T_{\mathrm{i}}$ lowers by $80^{\circ} \mathrm{C}$ on $\mathrm{Ce}_{0.5} \mathrm{Zr}_{0.5} \mathrm{O}_{2}$ with the best catalytic performance. The concentration of $\mathrm{O}_{2}$ has a significant effect on the rate-determined step during soot combustion. NO improves the catalytic activity of $\mathrm{Ce}_{0.5} \mathrm{Zr}_{0.5} \mathrm{O}_{2}$ and the $T_{\mathrm{i}}$ decreases by $30^{\circ} \mathrm{C}$. The oxygen storage capacity of $\mathrm{Ce}_{0.5} \mathrm{Zr}_{0.5} \mathrm{O}_{2}$ is the main season for soot combustion in an atmosphere lack of oxygen. $\beta$ oxygen participates in the soot combustion reaction and the mechanisms of spill-over and reduction/oxidation function synergistically.

\section{References}

[1] Y. Teraoka, K. Kanada, S. Kagawa, Synthesis of La-K-Mn-O perovskitetype oxides and their catalytic property for simultaneous removal of $\mathrm{NO}_{x}$ and diesel soot particulates, Appl. Catal. B: Environ. 34 (2001) 73-78.

[2] W.F. Shangguan, Y. Teraoka, S. Kagawa, Simultaneous catalytic removal of $\mathrm{NO}_{x}$ and diesel soot particulates over ternary $\mathrm{AB}_{2} \mathrm{O}_{4}$ spinal-type oxide, Appl. Catal. B: Environ. 8 (1996) 217-227.

[3] J.A. Neeft, W. Schipper, G. Mul, M. Makkee, J.A. Moulijn, Feasibility study towards a $\mathrm{Cu} / \mathrm{K} / \mathrm{Mo} / \mathrm{Cl}$ soot oxidation catalysts for application diesel exhaust gases, Appl. Catal. B: Environ. 11 (1997) 365-382.

[4] G. Mul, J.P.A. Neeft, F. Kapteijn, M. Makkee, J.A. Moulijn, Soot oxidation catalyzed by a $\mathrm{Cu} / \mathrm{K} / \mathrm{Co} / \mathrm{Cl}$ catalyst: evaluation of the chemistry and performance of the catalyst, Appl. Catal. B: Environ. 6 (1995) 339-352.

[5] S.J. Jelle, B.A.A.L. van Setten, M. Makkee, J.A. Moulijn, Molten salts as promising catalysts for oxidation of diesel soot: importance of experimental conditions in testing procedures, Appl. Catal. B: Environ. 21 (1999) 35-49.

[6] G. Saracco, C. Badini, N. Russo, V. Specchia, Development of catalysts based on pyrovanadates for diesel soot combustion, Appl. Catal. B: Environ. 21 (1999) 233-242.

[7] J. Oi-Uchisawa, A. Obuchi, R. Enomoto, S.T. Liu, T. Nanba, S. Kushiyama, Catalytic performance of Pt supported on various metal oxides in the oxidation of carbon black, Appl. Catal. B: Environ. 26 (2000) 17-24.

[8] J. Oi-Uchisawa, S.D. Wang, T. Nanba, A. Ohi, A. Obuchi, Improvement of Pt catalyst for soot oxidation using mixed oxide as a support, Appl. Catal. B: Environ. 44 (2003) 207-215.
[9] J. Kaspar, P. Fornasiero, M. Graziani, Use of $\mathrm{CeO}_{2}$-based oxides in the three-way catalysis, Catal. Today 50 (1995) 285-298.

[10] J. Lahaye, S. Boehm, P. Chambrion, P. Ehrburger, Influence of cerium oxide on the formation and oxidation of soot, Combust. Flame 104 (1996) 199-207.

[11] H. Sobukawa, Development of Ceria-Zirconia solid solutions and future, R\&D Rev. Toyota CRD 37 (1998) 1-5.

[12] Suda, H. Sobukawa, T. Suzuki, Synthesis of Ceria-Zirconia solid solution and its performance as catalytic promoter, R\&D Rev. Toyota CRDL 37 (1998) 3-12.

[13] L. Zhu, X.Z. Wang, Z.P. Hao, Catalytic performance of Ce/Zr oxides catalysts for soot combustion, J. Rare Earths. 22 (2004) 844-848.

[14] Z.Zhao, X.G. Yang, Y. Wu, A comparative study if Ni-based perovskite-like mixed catalysts for direct decomposition of NO, Appl. Catal. B. Environ. 8 (1996) 281-297.

[15] B. Dernaika, D. Uner, A simplified approach to determine the activation energies of uncatalyzed and catalyzed combustion of soot, Appl. Catal. B: Environ. 40 (2003) 219-229.

[16] P. Fornasiero, E. Fonda, R. Di Monte, G. Vlaic, J. Kaspar, M. Graziani, Relationships between structural/textural properties and redox behavior in $\mathrm{Ce}_{0.6} \mathrm{Zr}_{0.4} \mathrm{O}_{2}$ mixed oxides, J. Catal. 187 (1999) 177-185.

[17] P. Fornasiero, G. Balducci, R. Di Monte, J. Kaspar, V. Sergo, G. Gubitosa, A. Ferrero, M. Graziani, Modification of the redox behaviors of $\mathrm{CeO}_{2}$ induced by structural doping with $\mathrm{ZrO}_{2}$, J. Catal. 164 (1996) 173-183.

[18] J.P.A. Neeft, T.X. Nijhuis, E. Smakman, M. Makkee, J.A. Moulijn, Kinetic of the oxidation of diesel soot, Fuel 12 (1997) 1129-1136.

[19] T. Inui, T. Otowa, Y. Takegami, Enhancement of oxygen transmission in the oxidation of active carbon by the composite catalyst, J. Catal. 76 (1982) 84-92.

[20] R.T.K. Baker, J.J. Chludzinski Jr., Catalytic gasification of graphite by chromium and copper in oxygen, steam and hydrogen, Carbon 19 (1981) $75-82$.

[21] G. Mul, F. Kapteijn, J.A. Moulijn, Catalytic oxidation of model soot by metal chlorides, Appl. Catal. B: Environ. 12 (1997) 33-47.

[22] A. Galtayries, R. Sporken, J. Riga, G. Blanchard, R. Caudano, XPS comparative study of ceria/zirconia mixed oxides: powders and thin film characterization, J. Electron. Spectrosc. Relat. Phenom. 88-91 (1998) 951-956. 